\title{
aniki
}

Revista Portuguesa da Imagem em Movimento

Portuguese Journal of the Moving Image

\section{Figuras do ressentimento no cinema brasileiro dos anos 1990}

Ismail Xavier ${ }^{1}$

\section{Nota introdutória, por Lúcia Nagib}

Este texto de Ismail Xavier foi originalmente publicado no livro Estudos de Cinema 2000 SOCINE, organizado por Fernão Pessoa Ramos, Maria Dora Mourão, Afrânio Catani e José Gatti (Porto Alegre: Sulina, 2001, pp. 78-98). Sua reprodução aqui, após revisão, se deve a sua importância histórica no contexto da Retomada do Cinema Brasileiro, ocorrida a partir de meados dos anos 1990. O texto foi escrito no calor da hora, abordando filmes recémlançados que se tornariam simbólicos da Retomada, tais como: Como nascem os anjos, Murilo Salles, 1996; Baile perfumado, Paulo Caldas e Lírio Ferreira, 1996; Um céu de estrelas, Tata Amaral, 1997; Ação entre amigos, Beto Brant, 1998 e Central do Brasil, Walter Salles, 1998. Estes e muitos outros são amarrados por estratégias narrativas e representacionais semelhantes, que Ismail Xavier diagnostica como um gesto cinematográfico típico do período, num balanço que impressiona pelo alcance e a lucidez, apesar da proximidade dos fatos. A chave central, já tornada referência obrigatória para estudiosos da Retomada, é a figura do "ressentimento", com raízes filosóficas em Nietzsche e reelaboração por Scheler, que Xavier descreve como um refluxo à esfera privada de uma legião de personagens movidas pela desilusão ou indiferença política. Não por acaso, o fenômeno, segundo Xavier, inclui cineastas já veteranos na época, como Hector Babenco (Coração iluminado, 1998), Paulo Cesar Saraceni (O viajante, 1999) e Carlos Diegues (Orfeu, 1999), caracterizando-se, assim, não como ocorrência acidental, mas como culminância de um processo histórico iniciado nos anos 1980 com filmes como Eles não usam black-tie (Leon Hirszman, 1980), Das tripas coração (Ana Carolina, 1983), Inocência (Walter Lima Jr., 1983) e Anjos de arrabalde (Carlos Reichenbach, 1989). Ênfase especial cabe a Eles não usam black-tie, $o$ qual evidencia o embate entre a causa política de interesse coletivo e o ressentimento de cunho exclusivamente individual. Embora este último tenha vindo a prevalecer nos anos 1990, resta ainda, mesmo em momentos do mais completo niilismo como em Cronicamente inviável (Sérgio Bianchi, 2000), a possibilidade de redenção através do sorriso da criança sem teto ao final, que Xavier alinha aos "infantes onipresentes" no cinema mundial, "único universal que nos resta". O texto contém ainda o gérmen de outro conceito, igualmente importante, referente ao "encontro inesperado", cuja representação maior, tributária a Wim Wenders, se encontra em Central do Brasil e envolve justamente a criança inocente e o adulto ressentido. ${ }^{2}$ Tendo encontrado terreno fértil para seu florescimento na era neoliberal, o ressentimento, tal como abordado neste texto, se coloca, assim, como elemento essencial para a compreensão dos rumos que o cinema brasileiro iria tomar a partir dos anos 1990.

\footnotetext{
${ }^{1}$ Universidade de São Paulo, Escola de Comunicações e Artes, Departamento de Cinema, Rádio e Televisão, Cidade Universitária, São Paulo - SP, 05508-020, Brasil. ${ }^{2}$ Cf. Xavier 2003, 39-64.
} 
Em Coração iluminado (1998), Hector Babenco focaliza uma experiência de retorno ao país de origem vivida por um protagonista-cineasta de carreira internacional. A referência à cidade natal começa na sua adolescência e se expande até uma experiência limite da juventude, ficando elidida a vida adulta, momento em que, ao contrário de Truffaut, ele não parece ter encontrado em sua obra a superação dos golpes do passado. Sua viagem interior, seus fantasmas, reativam uma relação não resolvida com lances de opressão vividos desde a infância de menino judeu, de filho sempre repreendido pelo pai, de jovem que se envolve com um grupo excêntrico de intelectuais-artistas-boêmios-anarquistas e mergulha numa experiência de amour fou com uma jovem borderline. Em pleno clímax da paixão, ela é internada. Ele a resgata numa fuga que termina num pacto de morte, momento de exaltação romântica seguido, porém, de frustração, pois ambos são salvos por intervenção externa. Há o salto de décadas, e o protagonista retorna à Argentina já como cineasta consagrado, para fazer face ao estado terminal do pai e se atormentar na busca da antiga paixão. Com o pai, ele se reconcilia. Mas as tensões não se resolvem, pois a tentativa de encontro com a ex-namorada se frustra. O esquema é de ressentimento e encontra sua descarga em outra figura feminina, ao mesmo tempo real e imaginária. $\mathrm{O}$ filme joga com o mistério dessa mulher que perambula pela cidade e encarna encontros inusitados com o protagonista, experiência enigmática feita de projeções que desaguam num assassinato de estatuto ambíguo, ponto de acumulação das cargas do passado - a paixão perdida, a equação romântica de amor e morte cuja dimensão poética se adulterou. Seja qual for a leitura deste seu gesto de agressão, o dado notável é o próprio teor do seu recuo, ou seja, a sua fixação no passado, a necessidade de refazer percursos que termina numa miragem de liberação, como que para confirmar a presença das feridas não cicatrizadas. O ajuste de contas regressivo sinaliza cisões pessoais que a obra do cineasta não absorveu, seja ela qual for (nada sabemos de seu cinema). Há um senso de fracasso que a notoriedade apenas aguça, e revela-se aqui o mesmo mal-estar que vemos sinalizado por outras figuras que compõem toda uma galeria de personagens marcantes nos filmes da década.

Nesta fixação num estado ou situação do passado, ou em algo que acaba de se perder, há um potencial dramático ligado a projetos de vingança adiados, remoídos, que encontram no cinema uma variedade de manifestações que tornam a figura do ressentimento um dado notável que vale explorar, quase um diagnóstico nacional (ou continental). No filme de Babenco, a formulação do problema é mais enigmática, não sendo nada simples desatar os nós da experiência que resulta nesta combinação entre contundência do gesto e caráter simbólico do alvo, convidando o espectador a preencher os vazios e a refletir diante do choque da sequência final. 
Em muitos outros exemplos que cabe aqui examinar, o esquema é mais fechado, os conflitos mais definidos e observamos a busca de uma dramaturgia da clareza que marca o cinema recente. Dada a reiteração da personagem ressentida, o meu objetivo é aqui desenvolver um primeiro exame da questão, começando por caracterizar as formas pelas quais tal personagem se faz presente num cinema que tem se concentrado na dimensão psicológica da experiência, buscando a composição de conflitos que se estruturam segundo padrões consolidados pela tradição, seja no trato das questões da família, seja no trato da questão da violência na esfera pública.

$\mathrm{Na}$ esfera da vida privada, desenha-se um universo familiar em que, descartado o afeto, o encontro amoroso e a amizade, os dramas sinalizam uma dialética de desejo e frustração, de jogos de poder entre marido e mulher, pais e filhos, vizinho e vizinha que, temperados pela violência, marcam o efeito não apenas da pobreza material mas também do sentimento de rivalidade e de fracasso. Em figuras pares, de mesma origem ou destino, tal crise de relações se manifesta como ciúme do êxito alheio. Acontece, por exemplo, entre os amigos de Como nascem os anjos (Murilo Salles, 1996), ou dentro do grupo de trabalho, como em A causa secreta (1994), de Sérgio Bianchi, o mesmo cineasta que, em 2000, lançou Cronicamente inviável, filme que reúne os três polos desta experiência de emoções envenenadas, prepotência e pequenas tiranias: o polo doméstico, o do trabalho e o da ação comunitária. Na esfera pública, a crise dos projetos de transformação social, a tendência ao desencanto político e o mergulho no "salve-se quem puder" neoliberal encontram sua contrapartida em filmes que tematizam o ressentimento de figuras que já tiveram outra imagem menos ácida, que incorporava uma dimensão de esperança apta a observar manifestações de violência (como a do bandido rural e o marginal urbano) enquanto sinais de uma rebeldia pautada por alguma noção de justiça, o que levava a representação de tais figuras no cinema a adquirir uma feição romântica, num leque que ia de Glauber Rocha a Hector Babenco. Agora deslocado, tal como em Baile Perfumado (Paulo Caldas e Lírio Ferreira, 1996), o bandido deixa de fazer parte de um movimento rumo à revolta mais consequente, como um proto-revolucionário, e passa a ser visto como alguém contaminado por valores burgueses, cercado de perfume e whisky importado. Em Baile perfumado, do binômio "martírio e vaidade" desenhado nas narrativas em torno do cangaceiro resta apenas o segundo termo, e a sua imagem chega a compor, em certos planos, uma fisionomia de farsa. A música, a teatralização e a montagem o celebram como um ícone da cultura de massas, um herói disponível para o consumo: do romantismo passamos ao pop. Em outros filmes, como o já citado de Murilo Salles, os bandidos não fazem mais do que exibir a violência dos ressentidos, como Camarão, o mandachuva na favela. São figuras do 
expediente pragmático, sem maiores horizontes; no limite, profissionais do crime, como os bandidos de territórios de traficantes, assaltantes de caminhões, na fronteira do Paraguai, de Os matadores, de Beto Brant (1996). No novo cenário, crime e corrupção vêm ao centro da intriga política quando o filme dá ênfase aos esquemas de bastidor, às chantagens, aos esquemas de marketing eleitoral que empregam jornalistas assaltados pela culpa e pelo ressentimento, como em Doces Poderes (1995), de Lúcia Murat. Sistemas invisíveis de poder e determinações econômicas inelutáveis favorecem comportamentos regressivos.

\section{Compondo as referências}

As personagens pautadas por um "caráter destrutivo", de negação da vida, de vingança indeterminada contra o mundo não são uma exclusividade da década. Compõem um conjunto em que ressoam traços de décadas anteriores quando, seja no teatro, na literatura ou no próprio cinema, o ressentimento se fez figura nuclear, notadamente num filão que tem como eixo a tematização da decadência dos códigos patriarcais; caso, por exemplo, da literatura de Lúcio Cardoso e da dramaturgia de Nelson Rodrigues, ambas de significativa presença na produção cinematográfica desde os anos 1960, obras em que a frustração no casamento, a obsessão e o enredamento no passado geram cadeias de vingança que se somam a um mal estar no mundo do trabalho (arrivismo galopante) e no todo social, temeroso da violência dos pobres (que se dá quase sempre entre eles mesmos). Em foco a decadência familiar, o arrivismo ou a vingança da autoridade em crise, o que temos é a disseminação de traços que o cinema dos anos 1980 sinalizou no corpo social, em obras como Eles não usam black-tie (1980), Anjos de arrabalde (1989), Das tripas coração (1983) ou Inocência (1983). Carlos Reichenbach, Ana Carolina e Walter Lima Junior retomaram, nos anos 1990, esta questão em filmes significativos. A eles voltaremos. Mas antes uma exposição de referências teóricas e um comentário ilustrativo sobre o filme de Leon Hirszman servirão aqui de preâmbulo, pois nos ajudam a compor o quadro desejado face ao movimento do cinema (e da sociedade?) que interessa destacar.

Os sentidos da noção central aqui mobilizada ficarão delineados pela referência às situações práticas e sociais em que ela ganha lugar como comportamento reativo. Para uma referência mais específica, cito duas fontes tomadas aqui como baliza:

1) Genealogia da moral, Segunda Dissertação: “ 'Culpa', 'má consciência' e coisas afins”, em que Nietzsche comenta as formas de buscar a justiça no terreno do ressentimento e as tentativas de "sacralizar a vingança sob o nome de justiça - como se no fundo a 
justiça fosse apenas uma evolução posterior do sentimento de estarferido - e em seguida promover, com a vingança, todos os afetos reativos." 3

2) L'homme du ressentiment, de Max Scheler, notadamente o Capítulo 1, "Phénomenologie et sociologie du ressentiment", em que após comentário e citação de textos de Nietzsche, o autor observa: "O ressentimento é um auto-envenenamento psicológico de causas e efeitos bem determinados. É uma disposição psicológica, de certa permanência, que, pela repressão sistemática, libera determinadas emoções e sentimentos, em si normais e inerentes aos fundamentos da natureza humana, e tende a provocar uma deformação mais ou menos permanente do senso de valores, tanto quanto da capacidade de julgar. Tais emoções e sentimentos incluem, acima de tudo: o rancor e o desejo de vingança, o ódio, a maldade, o ciúme, a inveja, a malícia." ${ }^{4}$ Em seguida, Scheler ressalta o desejo de vingança como o mais importante.

No trato com esta noção-chave, procurarei me ater ao nível do que Scheler define como da "fenomenologia do ressentimento" quando caracteriza o processo de "auto-envenenamento psicológico" que pode se associar à procura da vingança que, por impotência, sentimento de inferioridade, se adia e, finalmente, se descola dos motivos iniciais e pode perder seu alvo, gerando excessiva suscetibilidade e agressividade indeterminada. Evoco brevemente este quadro apenas para lembrar as circularidades presentes na variedade de formulações, pois o meu objetivo é só observar a recorrência e o modo como a figura do ressentimento se apresenta, procurando uma visão preliminar de conjunto, preparatória a uma investigação mais fina, na qual estará mais presente a questão teórica. Por ora, a acepção do termo aqui adotada evidencia-se na lida com os filmes, tal como, de imediato, acontece no recuo que faço ao que pauta os conflitos centrais de Eles não usam black-tie.

Tal recuo nos coloca num terreno onde se defrontaram duas tendências da dramaturgia brasileira com que o cinema dialogou a partir dos anos 1960, uma voltada para a representação dos dramas familiares em conexão com situações de classe e com a vida política, outra voltada para o terreno das paixões, desejo e sexualidade, mais

\footnotetext{
${ }^{3}$ Ver Nietzsche 1988, 77.

${ }^{4}$ Ver Scheler 1970, 16, tradução de Lúcia Nagib. No original: "Le ressentiment est un auto-empoisonnement psychologique qui a des causes et effets bien déterminés. C'est une disposition psychologique, d'une certaine permanence, qui, par un refoulement systématique, libère certaines émotions et certains sentiments, de soi normaux et inhérents aux fondements de la nature humaine, et tend à provoquer une déformation plus ou moins permanente du sens de valeurs, comme aussi de la faculté de jugement. Parmi les émotions et les sentiments qui entrent en ligne de compte, il faut placer avant tout : la rancune et le désir de se venger, la haine, la méchanceté, la jalousie, l'envie, la malice."
} 
afetos ao que se analisa a partir dos instrumentos oferecidos pela psicanálise. ${ }^{5}$ Tomando Oduvaldo Vianna Filho como símbolo da primeira vertente e Nelson Rodrigues como emblema da outra, o que se pode verificar no cinema brasileiro dos anos 1970 aos anos 1990 é a hegemonia inconteste da segunda vertente, a que tem como eixo o autor de Toda nudez será castigada e as tendências a ele afinadas na lida com a experiência nacional. É por esta via que tem vindo a primeiro plano a questão do ressentimento, embora Oduvaldo Vianna Filho e Francesco Guarnieri, ambos praticamente fora das telas nos últimos vinte anos, a tenham também focalizado, como se verifica, de imediato, no exemplo de Eles não usam black-tie. No cinema de Leon Hirszman, a dimensão psicológica de desejo e frustração esteve sempre presente como referência a um comportamento regressivo que impede a superação de um estado de coisas que oprime as personagens, condena-as à circularidade. Isto se afirma desde a sua adaptação de A falecida (1964), texto em que o ressentimento contra a vida e a formulação de um ideal ascético alcança sua mais veemente expressão na personagem de Zulmira ${ }^{6}$. Na mesma tônica, Hirszman se interessou em sua adaptação (1972) do romance São Bernardo, de Graciliano Ramos, pela fragilidade do humanismo de Madalena e sua impotência diante do poder e do ciúme doentio de Paulo Honório, dado que a levou na mesma direção de Zulmira, embora sem a volúpia de mulher culpada e exibicionista. Tanto num filme quanto noutro, o casamento é o inferno e os maridos são personagens enredados num círculo de desconhecimento que só no final lhes oferece um momento de verdade. Em Eles não usam black-tie, Hirszman inverte os termos da equação e focaliza o casal operário como núcleo de uma vida solidária, deslocando a questão do ressentimento para o eixo do conflito de gerações. Adapta a peça inaugural de uma dramaturgia de esquerda que transforma o trabalhador - e sua ação pública mais emblemática: a greve - em centro da cena. O objetivo é discutir as condições da militância de classe; discutir que tipo de sujeito conduz as coisas numa direção construtiva, que estilo de luta pode ser visto como expressão de uma vontade de mudança, de consistente encarnação dos valores da solidariedade, e não apenas da vingança pessoal do pobre contra o rico pautada pelo ressentimento. Para separar de forma pedagógica o teor das ações - a construtiva (consciência de classe) e a reativa (rancor pessoal) -, o filme discute a questão do "que fazer?" a partir de um imperativo de contenção das emoções (como o ódio) e de desenvolvimento de uma capacidade de transcender as disposições individuais, que são psicológicas, rumo a um pensamento político.

O conteúdo mais particular da proposta política de GuarnieriLeon não está em discussão aqui, nem seu posicionamento específico

\footnotetext{
${ }^{5}$ Ver Xavier 1993.

${ }^{6}$ Ver Xavier 1998.
} 
diante da questão do movimento sindical no ABC paulista. Na linha adotada pelo filme, é o militante Sartini que encarna o ressentido de esquerda, que atrapalha porque "porra louca", vingativo, que perde o raciocínio nos lances de explosão pessoal confundida com a "necessidade" política. Na outra ponta do espectro, temos Bráulio, o militante operário que encarna a razão, sempre disposto ao debate e com espírito democrático. Acima de tudo, ele é o não ressentimento - sempre disposto a compreender o outro, ao debate político impessoalizado, sem vingança. Por isto mesmo é apresentado como alguém mais útil à luta sindical, coisa que a polícia também teria compreendido, escolhendo-o como alvo justamente quando está exercendo suas virtudes de figura da razão. Sua morte, uma vitória imediata do ressentimento que a direita explora, é um fato que Otávio - o personagem mais "redondo", figura da persistência - deve tornar simbólico para que, num plano mais mediato, Bráulio seja exemplo a seguir, tenha destinação histórica.

Otávio é o protagonista que se desenha fora do padrão do modelo impecável, com deslizes, mas sempre honesto e sensato, o que o torna o polo de identificação para a platéia. O drama realista, no caso, se assenta nas figuras médias, como ele e sua família. Esta é o outro eixo fundamental ao longo do qual as ações se organizam. Não por acaso, boa parte das cenas se dá na casa de Otávio, notadamente a do desenlace, quando após o clímax definido pela morte de Bráulio, o epílogo traz o casal, Otávio e Romana, a marcar a continuidade da vida e da luta paciente (contra a impaciência dos Sartini). Tanto quanto a morte de Bráulio, o ponto chave de Eles não usam black-tie é a traição do filho João à causa operária, que faz o drama doméstico evoluir em torno do conflito de gerações que, neste contexto, se articula à questão política. Embora a vida de João, de início, apresente elementos típicos de um futuro promissor (tem emprego, vai casar e a namorada revela uma gravidez que ele recebe muito bem), determinados problemas agem sobre traços seus que se desenham, no filme, como falhas de caráter. Há um diagnóstico de má formação. Motivos psicológicos, geradores de vulnerabilidade moral, estarão na base de sua conversão ao inimigo de classe. Para tanto, basta um gesto mais incisivo de uma figura da tentação na conversa da mesa do bar ("alie-se a quem tem poder, saia daqui para outra melhor, às favas os valores de solidariedade, estes que seu pai encarna"). A traição aqui tem desqualificação imediata porque afeta o polo oprimido, os que vemos apanhando da polícia, os que são explorados pelo baixo salário. Ou seja, no filme, a revolta contra o pai tinha de ser preparada e justificada pela conformação psicológica de João, notadamente pelo ressentimento como fator regressivo, impeditivo da lucidez, que explica as conversões à direita como esta do filho que vira dedo-duro e furador de greve, sem nenhuma consciência coletiva. O discurso crítico endereçado ao comportamento desviante (ou alienado) acentua uma estrutura 
psicológica de base dentro de uma tradição da cultura política que faz do ressentimento a mola dos equívocos da classe explorada. O homem injuriado sem lucidez projeta sua reação em vinganças pontuais (roubo, agressão) ou a um comportamento de gang que pode chegar ao limite de um engajamento fascista (em que a revanche contra o mundo atinge sua feição mais sinistra, provinciana, racista).

Black-tie é um dos raros filmes brasileiros de ficção a tematizar a vida de operários e um assunto como a greve e, dentro da discussão que interessa aqui, posso tomá-lo como uma espécie de filme-marco, dotado de um tom profético à revelia: a cena final é de homenagem a uma geração (a dos mais velhos) que traz consigo a tradição da consciência de classe, mas a personagem que se faria mais frequente nas telas, de lá para cá, seria a afinada a esse filho que pega o ônibus para viver a sua própria desventura na solidão, longe da cultura militante dos pais. Foi ele quem teve sucessores a partir da década de 1980, não Bráulio, nem mesmo Otávio. Os filmes de ficção preocupados com a militância operária entram em recesso e a dramaturgia do polo industrial em torno de São Paulo se ocupou mais, em sua crítica social, de outros aspectos da vivência, seja do operário, seja de outras figuras do trabalho na periferia, como em Anjos de Arrabalde, de Carlos Reichenbach, e em Beijo (1991), de Walter Luiz Rogério, no qual as questões da vida afetiva e os ressentimentos vieram a primeiro plano.

\section{Olho por olho, miopias vingativas}

Nos anos 1990, o eclipse da ação política em favor da vingança pessoal tem seu exemplo mais emblemático na figura do ex-militante de Ação entre amigos (1998), de Beto Brant. Temos aí a passagem ao psicológico como tema por excelência do filme que, quase como um teorema, expõe o movimento da figura do ressentimento e da fixação regressiva. Aqui, estamos no terreno de um projeto de vingança cujas coordenadas, motivo e alvo principal são tramados com todo o detalhe dentro de uma concepção do roteiro bem armado, que segue o formato da "filosofia da composição" de Poe, quando o escritor expõe sua concepção do conto e de sua eficácia: trama bem urdida, concisão, encerrar com a reviravolta que surpreende e redefine tudo com chave de ouro. É o que acontece neste filme, muito mais voltado para o primado da trama, da velocidade dos efeitos e do grand finale desconcertante, do que para uma exploração mais funda da subjetividade, das questões que dilaceram o ex-militante diante do fracasso de um projeto político e das feridas não esquecidas, diante da tortura e do assassinato da sua mulher pelo aparelho repressivo. O filme começa pela evocação perturbadora do terrorismo de Estado e dos seus helicópteros 
habituados a jogar prisioneiros vivos no mar. Acompanhamos a trama, no presente, de um militante que, embora vivendo um momento em que pode se ampliar o horizonte de atuação política com a vitória do candidato que ele assessora e que, por convite, deveria seguir no mandato em Brasília, opta por um projeto que, totalmente inserido na esfera da vida privada, significa, para ele, um ajuste de contas, sem nenhuma consequência política, com o torturador que nunca esqueceu e que acabou por encontrar depois de alguma investigação. Outros ex-militantes, amigos de sempre, são convidados a participar do plano de vingança num fim de semana que deveria ser de uma já rotineira pescaria. Monta-se um laboratório que reproduzirá o passado: uma ação em grupo, uma missão. Agora, sem nenhum horizonte político. E temos a fragilidade dos amigos que, embora sem convicção, se deixam enredar pelo projeto de reencontro com o torturador, o que pode ser tomado como um dado de precariedade pessoal que projeta sobre sua militância passada uma sombra de inconsistência. $O$ filme precisa, para a sua velocidade, da baixa resistência e da vulnerabilidade de todos diante do líder, polo mais impositivo, convincente porque tem a força de sua obsessão. Os amigos, até o último momento, fazem suas ponderações mas são ineptos na prática. Em favor da trama, eles deveriam assim ser, e não têm chances de alcançar maior densidade. Tal como no passado, as coisas vão dar errado. Lá, o número de variáveis era maior do que a equação dos militantes havia suposto, em sua subestimação do adversário e de seus métodos; aqui, equívocos grosseiros voltam a lançar no abismo a ação pretendida. $\mathrm{O}$ efeito da trama será justamente o da ligação entre um detalhe e outro (o do passado e o do presente), de modo a mostrar como a ironia do destino age nas duas ocasiões. A nova missão, embora atinja o alvo, paga o preço de uma revelação vinda da própria voz do torturador aposentado que se vinga quando já está fora de combate: um dos militantes traiu o grupo lá no passado. O surto colérico do protagonista não pode se interromper e, morto o inimigo, toda a carga de anos de ressentimento lhe dá energia para a corrida até a estação onde está o suposto, porém não de fato, traidor (exatamente o amigo que não o seguiu até o fim na insensatez). Lá chegando, ele mata o "traidor" num lance espetacular, à vista de todos. Preso, sua última imagem é de alguém arruinado, culpado de um homicídio que resultou do equívoco. A psicologia prevalece sobre o raciocínio político, e temos o exemplo de uma relação com o passado que, embora sirva de pretexto para a denúncia da tortura e do terrorismo de Estado, tem um teor regressivo, pois sugere a conexão direta entre ressentimento e condição de liderança na luta armada, tal como o faz $O$ que isso, companheiro? ${ }^{7}$

\footnotetext{
${ }^{7}$ Sobre o filme de Bruno Barreto, ver Xavier 1997.
} 
$\mathrm{Na}$ ordem familiar, reitera-se essa mesma articulação sui generis entre senso de impotência (diante de um fato consumado indesejável), agressividade mal administrada (dirigida a quem está na origem ou simboliza uma carência) e ruminação de projetos de vingança, ora adiados, ora conduzidos de forma a produzir efeitos desastrosos. São estórias diferentes e filmes desiguais no valor, mas é curiosa a simetria que se verifica entre o namorado rejeitado de Um céu de estrelas (Tata Amaral, 1996) e o marido traído do terceiro episódio de Traição (1998), intitulado Cachorro, dirigido por José Henrique Fonseca. Homens que perderam a autoestima invadem o espaço de suas mulheres para uma atitude de retaliação que termina com a sua própria morte, gerada por oscilações de um ressentido que se faz protagonista de uma vingança desajeitada que encontra vias de canalização da violência contra alvos deslocados (o ex-noivo mata a mãe de Dalva; o marido traído mata a mulher na recepção do hotel) e, no fim, contra si mesmos: em certo momento entregam a arma que trouxeram a alguém que os mata, cumprindo um desígnio autodestrutivo. A situação de Dalva e de Vítor, ilhados na casa cercada pela polícia e pela reportagem melodramática da TV, confere ao gesto dos dois protagonistas a dimensão de uma dignidade a preservar (é preciso que o impasse da relação se resolva entre eles e é preciso que o filme destaque a distância entre a relação real e o discurso da mídia). Já o marido traído, no caso da adaptação de Nelson Rodrigues, entrega a arma a um garçom que nada tinha a ver com a briga, e morre de forma grotesca. Há em Cachorro uma exploração menos feliz da ruminação do ressentido, mas vale ressaltar o ponto comum deste desenlace desafortunado que, afinal, reverbera nos anos 1990. O chofer de táxi de Perfume de gardênia, de Guilherme de Almeida Prado (1995), é abandonado pela mulher. Esta, num passe de mágica, resolveu ser atriz, seguindo sem brilho uma carreira que não poderia mesmo ser uma maravilha, enquanto ele passa a viver obcecado pela retaliação que adia 10 anos, até que monta um estratagema que talvez lhe permita um crime perfeito: passa a confessar outros crimes que não cometeu para que a polícia se acostume com a sua "mania" e não acredite quando ele vier a matar a ex-mulher. O esquema acaba não dando certo porque quem será preso, para desespero seu, será o seu próprio filho, acusado da morte da mãe. Mesmo sem o crime ou o ato mais radical de vingança, o rancor campeia na crise da figura masculina de Um copo de cólera (Aluízio Abranches, 1999), figura de que o romance de Raduan Nassar faz um raio X naquela auto-exposição típica da narrativa em primeira pessoa, traduzida com alguma dificuldade pelo filme. Tal personagem, em seu enfrentamento da figura feminina, mais forte e mais consistente do que ele, exibe de forma canônica a retórica do ressentido. Inseguro, se agita, cultiva o surto de cólera que, em outros terrenos e em outra classe talvez resultasse em ação mais efetiva, mas aqui é delírio, verborragia, a virilidade como domínio e agressão, fantasias infantis. Neste caso, vale a anatomia que disseca a 
circularidade de pequenas vinganças ruminadas e das catarses deslocadas de um herdeiro da cultura da Casa Grande, cuja inscrição na modernidade vemos na sua reação à figura da mulher urbana, não mais sinhazinha.

Um copo de cólera define um laboratório dramático enclausurado no espaço da fazenda. Em outro eixo, o do conflito entre gerações, um ambiente não menos clássico dos romances - a ilha do farol - oferece o espaço fechado para um drama de família em que a figura identificada com uma ordem patriarcal em crise destila seu ressentimento na nova geração. Falo de $A$ ostra e o vento (1997), de Walter Lima Jr., filme em que o homem arcaico do farol é pai da adolescente que vive intensamente seu "despertar da primavera”, para lembrar o título da peça de Frank Wedekind, $O$ despertar da primavera, de 1891. O pai condensa os traços da clausura e de um mundo condenado, reúne o ciúme de ontem (pela mulher que o largou) e o ciúme de hoje (pela filha, espelho da mãe, que se prepara para a recusa dessa prisão), sentimentos envenenados pela experiência passada que se desdobram numa postura de rechaço radical de qualquer arejamento da vida adolescente que o cerca, provocando o desastre geral em que a figura da promessa perde o jogo. Outra crise da Casa Grande, ligada ao tema da decadência em Minas Gerais, é a de Ana, protagonista de O viajante (1999), de Paulo Cesar Saraceni, que adapta o texto homônimo de Lúcio Cardoso. Viúva, dona do casarão de província, Ana é outra figura do ressentimento. Cerceada pelo código moral religioso, e pelos cuidados que deve ao filho deficiente mental, ela tem sua solidão rompida pela chegada do viajante. Há a sedução e o caso efêmero, seguido da culpa pela morte do filho em "acidente" que ela própria provoca; há as ilusões românticas dignas de uma adolescente, o ciúme digno de uma velha invejosa. O final sela a solidão da protagonista, não compensada pelos monólogos amargurados em que ela reitera o motivo clássico do silêncio de Deus.

Uma mistura perversa do público e do privado, já presente nos dramas de família na baixa classe média, pontuados pela intervenção da mídia (como em Um céu de estrelas), se faz mais sistemática quando o ambiente é a favela, e as relações de família e velhas amizades viram logo assunto geral. Em contextos sociais distintos, poluídos o encontro amoroso e a amizade, as histórias de vida privada sinalizam, no microcosmo de pequenos grupos, um horizonte de isolamento e dissenso geral (apesar do entrelaçado novelesco de alguns filmes, em que todo mundo tem a ver com todo mundo) no qual prevalece a violência como resposta não só à pobreza mas também ao fracasso. $\mathrm{O}$ darwinismo social irremediável encontra sua versão caricata e, a seu modo, contaminada pelo ressentimento que tematiza, em 16060 (1997), de Vinicius Mainardi. Há filmes em que figuras pares, de origem ou destino semelhantes, 
vivem uma crise de relações que pode encontrar versões sinistras, como na engrenagem que elimina o jovem que interpretou Pixote, assediado pelo ressentimento do irmão e pelo ódio da polícia - Quem matou Pixote? (José Joffily, 1996). Lances de inveja com destino trágico são comuns nos filmes que focalizam personagens das favelas que sucumbem a rompantes de violência, em que se somam, ao interesse ou ao roubo, o terreno do desejo e da inveja. É o caso dos meninos de Murilo Salles, notadamente Branquinha, em Como nascem os anjos, cujo perfil é o de uma subjetividade totalmente imersa no complexo dos quinze minutos de fama, inserida no circuito de uma cultura do narcisismo administrada pela mídia - a mesma que funciona na cultura dos jovens recrutados pelo narcotráfico, ansiosos por prestígio e dinheiro, não atraídos pela vida de caixa de supermercado, de office-boy ou de desempregado crônico. Se dá o mesmo no caso de Lucinho, amigo-irmão de Orfeu no filme Orfeu de Carlos Diegues (1999), que termina por assediar Eurídice, atiçado por um desejo que passa pela mediação do amigo artista e que termina por gerar a morte em parte "acidental" da moça (há uma pedra no meio do caminho, e uma bala quase perdida). O interessante aqui é este detalhe de roteiro que nada tem a ver com a peça de Vinicius de Moraes e se introduz como um dado de época, digamos assim, pela repetição que apresenta face aos outros filmes que lidam com um universo social semelhante. Em O Primeiro Dia (Walter Salles, 1998), o bandido que saiu da cadeia mata o amigo por força do constrangimento causado por uma engrenagem que os ultrapassa, e dá a ele, antes de morrer, tempo para que se lance numa liturgia do ressentimento, aqui proferida pelo que ela tem de diatribe universal. O pressuposto da conversa com Deus é o engodo geral e funciona como uma anti-louvação enunciada a partir da miséria maior de quem vê consumado um desenlace que era desde sempre quase certo.

Esta imprecação contra Deus, no desespero, é o que resta também ao Corisco de Corisco e Dadá (1996), de Rosemberg Cariry, embora o cangaceiro retenha neste filme seu estatuto de herói popular. No mais, a dimensão de revolta contra o quadro institucional e a estrutura de poder sai de pauta; os gestos e opções se reduzem ao encontro de um caminho pessoal dentro da ordem ou de suas brechas, prevalecendo a violência como atividade lucrativa. Mesmo na esfera do pobre predomina o bandido como fonte de violência repressora, intimidadora, que exerce o terrorismo e a intimidação para manter a sua imagem de machão, como estratégia de poder. A competição se acirra, e a luta pela sobrevivência põe o favelado contra o favelado, o habitante da periferia contra o habitante da periferia. Essa violência dos pobres entre si se faz sob os olhares pouco intervenientes do Estado ou de alguém de outra classe que, como o americano de Como nascem os anjos, dá mostras de seu 
humanismo e compreensão diante dos lances mais incivilizados dos que vêm do outro espaço social e invadem a sua propriedade.

Tomando a figura do estrangeiro, e suas vicissitudes na periferia, é singular - e de maior densidade - o tratamento dado a Sarah Bernhardt em Amélia (2000), de Ana Carolina. Parte-se aí do estranhamento mútuo de dois mundos numa tragicomédia que recompõe as questões psicológicas tematizadas antes pela cineasta no âmbito da vida privada, e agora numa metáfora que tem uma ressonância social e histórica mais definida. Ela sempre focalizou personagens femininas que se rejeitam, ou querem dominar uma à outra, e por fim revelam uma dependência mútua. É uma lógica nas relações pessoais que marca os filmes da diretora desde os anos 1970. Em Amélia, essas relações se projetam numa metáfora do tipo nacional, nos eixos centro-periferia e colonizador-colonizado. Com originalidade, o filme faz com que Sarah Bernhardt se encontre com as três mulheres do interior de Minas em pleno Rio de Janeiro após a morte de sua camareira, a Amélia do título (e do famoso samba), que era a terceira irmã desta família mineira. Não é projeto da atriz francesa se contaminar com a periferia, representada pelas mulheres, nem elas querem tal interação. São mundos distantes que, no entanto, se encontram e se contaminam. Sarah Bernhardt proclama sua diferença em relação às brasileiras, mas também tem o seu lado histérico, de dependência, embora diga que conquistou o mundo. Amélia é a irmã que perdeu a identidade, que se tornou um prolongamento da atriz francesa muito antes de morrer, mas também pode representar uma espécie de vitória da oprimida, pois criou em Sarah Bernhardt um tipo de carência que só ela pode suprir. Com a sua morte, essa carência só pode ser resolvida pelas suas substitutas, as duas irmãs e a empregada, apesar de a sua relação com elas ser conturbada. Tudo vira uma terrível vingança no final, quando Francisca tira as almofadas onde Sarah deve cair atrás do cenário da ópera, e a atriz vem a perder a perna em função da queda. Há, portanto, uma simbiose em Amélia entre a francesa e as brasileiras. Simbiose assimétrica, desigual. Mas ainda assim simbiose, dependência e ressentimento mútuos. Essa é uma maneira nova de trabalhar a relação entre colonizadores e colonizados, reiterada quando o filme mostra, em seu epílogo, as brasileiras fazendo uma figuração ridícula num espetáculo parisiense, encerramento em que o kitsch é total, o índio falso, tudo pura aparência. Mas a imagem da Sarah Bernhardt não é menos terrível: é uma mulher de perna de pau declamando Gonçalves Dias, uma diva que perde a pompa enquanto as três caipiras, com suas picuinhas, dão nova conformação ao seu mundo. 


\section{Espaços de redenção}

O quadro aqui resumido não é absoluto, e exemplos significativos, que fizeram sucesso no cinema dos anos 1990, mostram quanto há, no público, uma receptividade ao que se manifesta como um antídoto a tal mal-estar, o que quase sempre vem da comédia, seguindo o imperativo de conciliação do gênero. $O$ caso mais interessante nesta linha, num cinema urbano sem crispações, disposto a fazer da conversa informal e da fala direta ao espectador os canais de fluência que dão o tom, é Amores (1998), de Domingos de Oliveira. Ele funciona, neste contexto, como se tivesse sido programado para negar ponto a ponto esta pauta das frustrações, ressentimentos, retaliações. Tal como no insular $A$ ostra e o vento, temos aqui um pai, separado da mulher, que tem de educar a filha e enfrentar as angústias de quem vive tal relação pai-filha na forma do fascínio e do medo de uma perda que se confirma a cada passo, a cada dia. Com a diferença de que, neste caso, a figura do pai, centro de consciência das tramas e mestre de cerimônias deste teatro, já superou a crise com a ex-mulher, sem mágoas, como supera também o sentimento de posse dirigido à filha e a tudo o mais, no que é acompanhado pelas outras personagens, de modo que os tropeços se sucedem com humor e as perspectivas de solução se confirmam ao final. O espaço urbano do Rio de Janeiro e suas conexões oferecem o caldo de cultura para uma assimilação das vicissitudes da vida afetiva moderna.

Tal arranjo não é exclusivo, porém, do mundo urbano. E a originalidade de um filme como $\mathrm{Eu}$, tu, eles (Andrucha Waddington, 2000) é a de colocar uma experiência de conciliação (embora tensa) em pauta em pleno sertão dos patriarcas, um sertão que mudou e aparece agora em versões distintas. O filme trabalha a unidade familiar com um certo grau de isolamento semelhante ao de Vidas Secas. Há uma pequena cidade perto, há o mundo do trabalho e há relações de poder. Claro que a chave é outra. Há a ausência de dois elementos que costumavam estar presentes nos filmes situados no sertão: a violência e a religião. Ao contrário, o que existe é a capacidade de as personagens chegarem a soluções de compromisso. A protagonista, Darlene, sai da cidade, tem um filho, volta com ele crescido e aceita se casar com o homem mais velho, Osias. Pragmática, ela se casa não por afeto ou desejo sexual, mas como um dispositivo de sobrevivência. No entanto, Osias faz com que ela trabalhe sem parar, quase como uma escrava. Diante da figura do patriarca, do poder, ela não bate de frente; monta um estratagema: olha em volta e seduz o primo do patriarca. Ele é uma figura mais afetiva, que lhe dá atenção, mas não é um homem sedutor. No triângulo peculiar, o papel do primo é cozinhar, levar a comida para Darlene no leito. É um outro arranjo. O que lhe falta, a ela que tem a segurança com o patriarca Osias e a proteção do afeto do primo, é 
uma vida sexual menos morna. Darlene busca um terceiro amante, o forasteiro jovem. Cada novo personagem que entra no jogo corresponde a uma recomposição dos demais. Formado o quarteto, este nunca se mostra estável. No final, Osias exerce o patriarcado e registra em seu nome todas as crianças que ela teve. No derradeiro plano, um plano geral filmado de cima, vê-se o quarteto. O primo e o jovem forasteiro entram na casa e são acompanhados por Darlene, deixando Osias sozinho lá fora. O espectador espera que finalmente ocorra uma ruptura. Mas a mulher volta e olha para o marido de frente: parece que um novo arranjo é possível, mas há o lado do impasse, da tensão não resolvida. Descarta-se a violência (a mesma presente na maioria dos outros filmes que lidam com a vida conjugal), o estereótipo da honra do macho ofendida. O filme gira em torno de acordos pragmáticos: não há ideologia, não há religião, não há uma pauta moral. Há expedientes que, embora na esfera popular, lembram Amor \& Cia (1998), de Helvécio Ratton, cujo tema é o adultério. Nele, se descartam as noções aristocráticas de reputação, de lavar a honra com sangue, para que prevaleçam os interesses pragmáticos da empresa. $\mathrm{Em} \mathrm{Eu}$, tu, eles, não foi interesse do diretor forçar os conflitos latentes, ou politizá-los. O filme vê com simpatia a administração da vida tal como ela é feita pelos personagens populares. Vale aí o pragmatismo como expediente, a manipulação que Darlene faz dos homens em função de seu interesse, escapando aos limites da ordem familiar. Dado que a moldura da situação é a sociedade patriarcal, a resposta dela é inteligente, invertendo o jogo e deixando o rancor para a figura masculina.

Para encontrar uma personagem positiva, Dois Córregos (Reichenbach, 1999) faz o recuo ao passado e focaliza um militante da guerrilha que é, em tudo, o oposto da figura do ressentimento, pelo equilíbrio e ações nobres, pela marca deixada na sobrinha, foco da recordação que estrutura o filme. No início, ela chega ao sítio da família para uma reintegração de posse que se dá nos anos 1990, ocasião para a percepção do contraste entre as figuras grotescas que a cercam (o advogado que só pensa em cifras, os seguranças, a culpa dela própria diante da situação que lhe joga na cara que tudo persiste) e a memória do tio desaparecido aguçada pela volta ao espaço em que ocorreu o contato inesquecível quando era adolescente, momento de descobertas. A memória traz um humanista de mão cheia, homem sensível (a música), pai (a memória dos filhos de quem foi obrigado a se distanciar e a quem deixa um legado espiritual nas cartas que enterra no sítio), marido (dá sinais de compreensão face à ex-mulher, mãe dos meninos), amante (em seu encontro com a empregada do sítio), tio e conselheiro (o bom senso na lida com o fascínio das adolescentes, a sobrinha e uma amiga). Sua nobreza se realça pelos contrastes; seja com a própria irmã dona do sítio, burguesa mesquinha que não aparece em cena, 
mas de quem se fala muito; seja com figuras masculinas machistas, em particular, o soldadinho fascistoide, namorado da empregada. Escondido da repressão, ele permanece no sítio num tempo de espera preenchido por este leque de relações avivadas pela identificação entre sujeito (a sobrinha) e objeto (ele mesmo) da memória. Até que o ressentimento entre em ação: o soldado ciumento vem fazer escândalo no sítio, obrigando o militante a se mostrar para defender a mulher que ama, comprometendo a sua clandestinidade. $\mathrm{O}$ militante toma o rumo do rio, desatraca o barco e desaparece. Completado o ciclo, restam as imagens de desencanto na volta ao presente, enquanto ouvimos as palavras do militante dirigidas à nova geração representada pela imagem de seus filhos sós na estrada. Figura portadora dos bons valores, até o limite da idealização, tal personagem tem uma dimensão dialógica no cinema dos anos 1990, um contraponto, tal como, de formas distintas, encontramos em Amores e Central do Brasil (Walter Salles Jr., 1998), cada qual na sua chave.

Se em Dois Córregos o antídoto face aos dramas do ressentimento desagua na recordação de um encontro da adolescência, em Central do Brasil, alegórico desde seu título e em toda a sua parábola de redenção moral, o contraponto a este espírito de vingança contra o mundo se constrói no motivo do encontro inesperado, agora entre uma velha dama indigna e uma figura de inocência. O roteiro assenta numa polarização entre bem e mal sem a qual a reviravolta final não teria o mesmo efeito. É preciso que Dora concentre em si muito do que se viu, nas telas, de egoísmo, rancor, disposição ao engano, insensibilidade, compondo o tipo "cada um por si e Deus contra todos", quando a fórmula vira realismo e perde o humor que tinha em Macunaíma (Joaquim Pedro de Andrade, 1969). É preciso que as pessoas enganadas estejam no limite da carência e da vulnerabilidade para que a atitude ignóbil de Dora não deixe dúvidas quanto às proporções de sua vilania que nem mesmo honra a dimensão mercantil de sua prática de escrevente tão útil na aparência. E é preciso que a vulnerabilidade e o teor da ameaça à inocência desprotegida cheguem ao paroxismo para que Dora, não sem oscilações, se digne a enveredar pelos caminhos da compaixão. Daí o horror da estação Central, dos crimes à luz do dia, do tráfico de crianças, tudo o que Dora e Josué deixam para trás no movimento rumo ao campo idealizado, percurso que a velha senhora impaciente e o menino às vezes petulante, às vezes queixoso, mas sempre inteligente, devem fazer para que ele possa ser entregue à família. Cumpre-se aqui o roteiro à Wim Wenders dessa relação entre adulto e infante que começa hostil, tem tropeços, evolui e chega ao amor, numa aclimatação às vicissitudes brasileiras que é realçado ao longo da jornada. O filme faz convergir novos lugares, amplia o horizonte, na medida em que a visão se areja nos espaços abertos. E há um ponto de inflexão fundamental, vivido na pequena cidade tomada 
pela procissão, pela exaltação religiosa, condição para que Dora tenha a morte simbólica e renasça outra, redimida, iluminada, momento a partir do qual tudo flui em direção ao desenlace que sela o encontro entre ela e o garoto como experiência redentora. O garoto aí é o Pixote que encontra a figura materna substituta e se salva, ao contrário do menino de rua original que busca a mãe provedora na prostituta - mas esta se comporta segundo a pauta do real, não da parábola, e repõe, no desenlace, os impasses que sempre marcam os finais de Babenco. Josué é o menino do cinema contemporâneo que partilha com o italianinho de $A$ vida é bela (Roberto Benigni, 1997) e com a antecessora Alice, em Alice nas cidades (Alice in den Städten, 1974) de Wenders, a graça de uma volta ao lar, apesar de tudo. Meta feita impossível para tantos outros garotos que dominam as telas, notadamente nos anos 1990, como encarnações derradeiras do humano, do que seria ainda defensável num cinema que observa o seu entorno como uma terra devastada onde os adultos não convencem ninguém de que acreditam, para valer, em algum valor alheio ao interesse imediato (e as coisas vão mal porque a mão invisível não funciona como esperado). Tais crianças despontam como as últimas personagens a sancionar o drama sentimental levado a sério e sem subterfúgios, a tornar possível um esquematismo moral ofensivo para quem procura algo mais realista, distante das parábolas de inspiração bíblica. Destas, Walter Salles, com seu talento, nos ofereceu a mais bem-sucedida, aquela em que o final lacrimoso é lance de melodrama que, no entanto, encontra a sansão estética na poeira de contundências sociais que o perfil documentarizante de Central do Brasil consegue levantar, seja em suas imagens de abertura, seja na estrada. O desfile de rostos a ditar cartas tem seu encanto, tanto quanto algumas imagens desse percurso de migração às avessas, que dialoga com os filmes do Cinema Novo, embora repita o clichê anti-urbano apoiado na polarização ética entre o arcaico (bem) e o moderno (mal), um clichê que o cinema brasileiro já havia aprendido a descartar.

\section{Um filme síntese: o ressentimento dos pobres e o dos ricos}

Os dramas sérios empenhados na composição de parábolas morais cujo desenlace é de redenção são raros hoje. Neste sentido, o filme de Walter Salles é o mais nítido dos contrapontos ao tom dominante num cinema brasileiro mais atento às experiências de fracasso, frustração e morte. Cada filme, tomado isoladamente, tende a assumir, de forma peculiar e às vezes questionável, uma postura estritamente psicológica ou moral face à experiência. Considerado, no entanto, em seu efeito global, esse cinema recente expressa as angústias que advêm da própria textura social marcada pelo senso de impotência diante de engrenagens gigantescas de poder que permanecem fora do alcance, no espaço off, talvez porque refratárias 
à representação visual, pelo menos dentro das formas escolhidas pelos cineastas. Embora aparentemente abstratas, estas engrenagens exercem papel fundamental, condicionando variadas formas de violência, incluindo as que se manifestam na vida privada enredada nos desejos miméticos e no circuito do ressentimento.

Dada essa configuração geral do cinema e o sentido que ela sugere, é contundente a provocação de Sérgio Bianchi feita em Cronicamente inviável, título que por si só já é um diagnóstico. Tratase de um filme que, por levar o mal-estar ao paroxismo, vai ao ponto limite da discussão moral, tornando mais forte o senso da reflexividade, principalmente porque a fonte do comentário over que pontua muitas sequências é a do narrador-professor que se revela, gradativamente, ele mesmo uma figura-chave do ressentimento. $\mathrm{O}$ filme de Bianchi, ao contrário da diatribe conservadora, exibe a ironia ferina de quem tem a lucidez de não poupar o próprio centro do discurso. O ressentimento se escancara, vira tema de conversa, atinge a condição de traço fisionômico de uma classe média feita de denegações, infeliz porque está no seu lugar e gostaria de estar fora dele. Composição em mosaico, a montagem justapõe lugares nacionais emblemáticos, palcos de experiências-limite de confronto, feitas de ofensa e crueldade exatamente entre os que estão por baixo, ou levemente com a cabeça acima da superfície. São os elos menores da corrente que podem se apresentar em carne e osso, como o patrãozinho xingado que já não representa a ordem do capital em sua potência mais efetiva. Em seu começo, o filme explicita o problema da representatividade: como tornar visível a lógica da iniquidade? e poderia ter avançado mais nesta direção. De qualquer modo, seu esforço de totalização põe aqui os brasileiros no laboratório do medo, das hipóteses idílicas ironizadas, dos ódios recíprocos que desmontam o mito da simpatia e do jeitinho, dos comentários ressentidos que azedam a alegria e o carnaval. É a gangorra entre a falsa conciliação e o surto colérico da empregada que não tem saída; o desencanto do rico, mas não tão rico, alienado que não queria estar aqui; a má consciência da mulher arrivista; o exibicionismo do homossexual metido a esperto; enfim, a mediocridade meditativa do professor contrabandista. Uns com vergonha do que são, outros com vergonha de onde vivem, o que lhes resta é partilhar o preconceito entre as regiões, a luta de classes, o ódio recíproco das etnias, a guerra dos sexos, a paranoia das cidades, a incompetência dos inconformados, a perversidade dos bolsões onde ainda se vive junto à natureza, para destruí-la. Entre estes cacos, o nacional é experiência à revelia, ou espasmo de festa. No entanto, se impõe, pela própria estrutura do filme, como um território e como uma sina. A mesa do restaurante chique se faz o cenário do ressentimento dos ricos que fazem seu brinde a Nova York e se queixam como classe pouco à vontade neste país em que vivem na condição de "ocupantes" (para usar a expressão de Paulo Emilio Salles Gomes), 
sem assumir responsabilidades sociais. Este é o ponto para onde converge, no filme, o desfile de egoísmo, de mau caráter, de tramazinhas de amor próprio, ridículas pretensões, inveja, improbidade, refinamentos no maldizer. Aos que usufruem de um arremedo de filosofia, é incômodo o silêncio de Deus, motivo de muita conversa e de imagens aéreas reiteradas, circulares, obsessivas em torno do Cristo no Corcovado. Tudo na postura do filme exala uma provocação inconformada, embora às vezes ele também se contamine do ressentimento de suas personagens. Sua estratégia, no entanto, é insistir, exasperar, explorar certas repetições, tal como na sequência final, quando o olhar e a escuta insistentes se dirigem à fé radical, patética, louca, mas não menos efetiva dessa mãe sem teto cuja pauta de conselhos ao filho faz a lista dos valores anulados na prática pelo dinamismo da sociedade. Resta, ao final, o sorriso do menino, imagem derradeira destes infantes tão onipresentes que, também neste filme, dão a tônica, agora como uma reserva ecológica não poluída, mas em vias de sê-lo, pois aqui caridade rima com frivolidade, num convite à agressão mútua dos infelizes entre si.

A violência dos pobres entre si e os surtos coléricos de personagens fracassadas é expressão de uma experiência marcada pelo senso de impotência diante das engrenagens sociais, vivência de becos sem saída que, no máximo, oferecem uma figura intermediária, um capataz qualquer, para quem pode ser canalizada a revolta. Como observei, as esferas efetivas do poder permanecem uma espécie de buraco negro fora do alcance ou mesmo do entendimento, pois a estrutura do jogo montado pelo cinema atual não tem propiciado voos nesta direção. Não surpreende que o mecanismo recorrente, considerada a hegemonia da cena familiar, envolva obsessão, enredamento no passado, cadeias de vinganças frustradas. Proclamada uma pauta de valores centrada na igualdade, o quadro institucional promete representação democrática, a publicidade atiça o desejo e simula oportunidades de consumo, mas o mundo prático frustra as expectativas porque, nele, igualdade e oportunidade são pautas de realização impossível. Diante dos obstáculos, e suposta a igualdade, resta a pergunta: porquê ele e não eu? A disputa perde limites, compondo um mundo onde é difícil encontrar personagens portadoras de valores que transcendam o lance imediato de realização de um desejo nem sempre legítimo, e cabendo à competição, evidenciada como a regra geral do sistema, definir a clivagem entre vencedores e vencidos. O derrotado se transforma num injuriado que, na dificuldade de superação efetiva, rumina os projetos de vingança, canaliza a energia para esquemas obsessivos e termina por extravasar um impulso adiado e energias acumuladas, numa autoagressão ou numa ação deslocada onde dá tudo errado. Inocência? Somente na figura do infante, espécie de reserva do que ainda pode gerar compaixão, encarnar valores, prometer. Ele é, por 
isto, personagem central no cinema mundial contemporâneo cujo lema parece ser: a criança é o universal que nos resta.

\section{BIBLIOGRAFIA}

Nietzsche, Friedrich. 1988. Genealogia da moral: um escrito polêmico. Tradução de Paulo Cesar Souza. 2a ed. São Paulo, Editora Brasiliense.

Scheler, Max. 1970. L'homme du ressentiment. Paris: Gallimard.

Xavier, Ismail. 2003. "Brazilian Cinema in the 1990s: the unexpected encounter and the resentful character." In The New Brazilian Cinema, Lúcia Nagib (org.), 39-64. Londres/Nova York: I.B. Tauris.

- - - 1998. "A falecida e o realismo, a contrapelo, de Leon Hirszman”. Novos Estudos CEBRAP, n. ${ }^{\circ} 50$ (março): 191-210.

———. 1997. "Olhar neutro e banalização: O que isso, companheiro?" Praga, n. ${ }^{\circ} 3$ (setembro): 141-153.

—_- 1993. "Pais humilhados, filhos perversos: Arnaldo Jabor filma Nelson Rodrigues”. Novos estudos CEBRAP, n. ${ }^{\circ} 37$ (novembro): 59-81.

\section{FILMOGRAFIA}

16060 [longa-metragem]. Dir. Vinicius Mainardi. Brothers in Pictures, Brasil, 1997. 89 mins.

A causa secreta [longa-metragem]. Dir. Sérgio Bianchi. Agravo, Brasil, 1994. 100 mins.

A falecida [longa-metragem]. Dir. Leon Hirszman. Meta Produções Cinematográficas, Brasil, 1964. 85 mins.

Ação entre amigos [longa-metragem]. Dir. Beto Brant. Dezenove Som e Imagens Produções, Brasil, 1998. 76 mins.

Amélia [longa-metragem]. Dir. Ana Carolina. Crystal Cinematográfica, Brasil, 2000. 130 mins

Amor \& Cia [longa-metragem]. Dir. Helvécio Ratton. Quimera Filmes, Brasil, 1998. 99 mins. 
Amores [longa-metragem]. Dir. Domingos de Oliveira e Priscilla Rozenbaum. Bradesco; TV Zero, Brasil, 1998. 100 mins.

Anjos de arrabalde [longa-metragem]. Dir. Carlos Reichenbach.

Produções Cinematográficas Galante, Brasil, 1989. 104 mins.

Baile Perfumado [longa-metragem]. Dir. Paulo Caldas e Lírio

Ferreira. Riofilme, Brasil, 1996. 93 mins.

Beijo [longa-metragem]. Dir Walter Luiz Rogério. Brasil, 1991.

Central do Brasil [longa-metragem]. Dir. Walter Salles Jr. Brasil, 1998. 112 mins.

Como nascem os anjos [longa-metragem]. Dir. Murilo Salles. Empório de Cinema, Brasil, 1996. 97 mins.

Coração iluminado [longa-metragem]. Dir. Hector Babenco. HB Filmes, Oscar Kramer, Flach Film, Brasil/Argentina/França, 1998. 130 mins.

Corisco e Dadá [longa-metragem]. Dir. Rosemberg Cariry. Cariri Filmes, Brasil, 1996. 101 mins.

Cronicamente inviável [longa-metragem]. Dir. Sérgio Biachi. Agravo, Brasil, 2000. 101 mins.

Das tripas coração [longa-metragem]. Dir. Ana Carolina Teixeira Soares. Crystal Cinematográfica, Brasil, 1983. 108 mins.

Doces Poderes [longa-metragem]. Dir. Lúcia Murat. Taiga Filmes, Brasil, 1995. 97 mins.

Dois Córregos [longa-metragem]. Dir. Carlos Reichenbach. Dezenove Som e Imagens, Brasil, 1999. 112 mins.

Eles não usam black-tie [longa-metragem]. Dir. Leon Hirszman. Leon Hirszman Produções, Brasil, 1980. 123 mins.

$\mathrm{Eu}, \mathrm{tu}$, eles [longa-metragem]. Dir. Andrucha Waddington. Brasil, 2000. 102 mins.

Inocência [longa-metragem]. Dir. Walter Lima Junior. L.C.B. Produções Cinematográficas, Brasil, 1983. 118 mins.

O Primeiro Dia [longa-metragem]. Dir. Walter Salles e Daniela Thomas. Brasil, 1998. 75 mins.

O viajante [longa-metragem]. Dir. Paulo Cesar Saraceni. Shater Produções Artísticas, Brasil, 1999. 117 mins. 
Orfeu [longa-metragem]. Dir. Carlos Diegues. Rio Vermelho, Brasil, 1999. 110 mins.

Os matadores [longa-metragem]. Dir. Beto Brant. Casa de Produção, Brasil, 1996. 90 mins.

Perfume de gardênia [longa-metragem]. Dir. Guilherme de Almeida Prado. Star Filmes, Brasil, 1995. 118 mins.

Quem matou Pixote? [longa-metragem]. Dir. José Joffily. Coevos Filmes, Brasil, 1996. 120 mins.

Traição: 3 Estórias de Nelson Rodrigues [filme em episódios]. Episódios: O Primeiro Pecado; Diabólica; Cachorro. Dir. Arthur Fontes, Claudio Torres, José Henrique Fonseca. Brasil, 1998. 95 mins.

Um céu de estrelas [longa-metragem]. Dir. Tata Amaral. Casa de Produção, Brasil, 1996. 80 mins.

Um copo de cólera [longa-metragem]. Dir. Aluízio Abranches. Ravina Filmes, Brasil, 1999. 65 mins. 